\section{A dextran slide test for blood grouping}

\section{I. K. EVANS From Booth Hall Children's Hospital, Manchester}

Dextran has been used for the detection of incomplete Rhesus antibodies (Grubb, 1949; RichardsonJones, 1950) and immune anti-A and anti-B (MunkAndersen, 1956). Other high molecular weight compounds such as gum acacia (Sturgeon, Cedergren, and McQuiston, 1964), polyvinyl pyrrolidone (Szymanski, Valeri, McCallum, Emerson, and Rosenfield, 1968), and polybrene (Lalezari, 1968) have been used in automatic apparatus for blood grouping and antibody detection. In this rapid slide test, dextran is used to induce rouleaux in the presence of antibody: when rouleaux are dispersed by the addition of saline, the cells sensitized by antibody remain bound together, and may be clearly distinguished. The method works well with a wide range of antibodies. A similar principle has been utilized in an AutoAnalyzer method, but with polybrene- and enzyme-treated cells (Lalezari, 1968).

\section{Method}

1 To each half of a slide is added one drop of high molecular weight $(\mathrm{Mw} 150,000)$ dextran in 3\% solution.

2 To one side is added a drop of antiserum: to the other side is added a drop of $\mathrm{AB}$ serum.

3 One drop of a $10 \%$ suspension of cells is added to each side of the slide.

4 The antiserum/dextran/red cell suspensions are mixed.

5 For warm-acting antibodies the slide is placed in an incubator: cold antibodies may be left at room temperature.

6 After three minutes the slide is rocked for a minute at room temperature to mix the cells. Two drops of saline are added to each half of the slide which is rocked to disperse any rouleaux. The result is read with the naked eye.

The method has given good results with four anti-Kell, one anti-k, three anti-Le ${ }^{a}$ and three anti-Le ${ }^{b}$, two anti-C, one anti-c, three anti-D, three anti-E, and one anti-M sera. Two anti-S and two anti-P sera gave only moderately good results, and there was no enhancement of agglutination with one anti-P and one anti-Lu ${ }^{\mathrm{a}}$ serum. With one anti-Fya, one anti-S, and one anti-e the result was poor. When Received for publication 5 August 1970.

\section{A quick method for reading the indirect haemagglutination test}

\author{
BRIDGET G. WOODHEAD AND D. S. RIDLEY From the \\ Hospital for Tropical Diseases, London
}

Indirect haemagglutination tests are usually performed in plastic plates with U-shaped wells. The test sera and the antigen (tanned and sensitized red cells) are mixed in the wells, the plates are sealed and left for the cells to settle. The results are read on the pattern of cell sedimentation. In our experience with this technique the end point is difficult to read, and the results are inconsistent unless a considerable amount of time and care is given to washing the plates. The method described here using glass well slides and a rotator in place of the plastic plates is simple, it is quicker and easier to read than the standard method, and it gives highly reproducible results with a clear-cut end point.

\section{Method}

The cells used were human $O$ cells as supplied by Received for publication 12 August 1970.

\section{A dextran slide test for blood grouping-continued}

tested against a panel of D-positive cells, including $\mathrm{D}^{\mathrm{u}}$ cells, satisfactory results were obtained in all cases. The test works particularly well with anti-Kell.

This work was done at the Regional Blood Transfusion Service, Manchester. I am indebted to Dr F. Stratton and Dr P. H. Renton for much helpful advice.

\section{References}

Grubb, R. (1949). Dextran as a medium for the demonstration of incomplete anti-Rh agglutinins. J. clin. Path., 2, 223-224.

Lalezari, P. (1968). A new method for detection of red blood cell antibodies. Transfusion (Philad.), 8, 372-380.

Munk-Andersen, G. (1956). A dextran serum medium for the demonstration of incomplete anti-A and anti-B; direct conglutation test for demonstration of in vivo sensitization with incomplete ABO antibody of red cells of newborn infants. Acta path. microbiol. scand., 38, 259-272.

Richardson-Jones. A. (1950). Dextran as a diluent for univalent antibodies. Nature (Lond.), 165, 118-119.

Sturgeon, P., Cedergren, B., and McQuiston, D. (1963). Automation of routine blood typing procedures. Vox Sang. (Basel). 8, 438-451.

Szymanski, I. O., Valeri, C. R., McCallum, L. E., Emerson, C. P. and Rosenfield, R. E. (1968). Automated differential agglutiny ation technic to measure red cell survival. I Methodology. Transfusion (Philad.), 8, 65-73 